\title{
The potential role of Antarctic krill faecal pellets in efficient carbon export at the marginal ice zone of the South Orkney Islands in spring
}

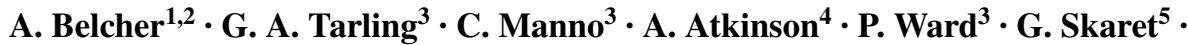 \\ S. Fielding ${ }^{3} \cdot$ S. A. Henson ${ }^{1} \cdot$ R. Sanders ${ }^{1}$
}

Received: 16 October 2016 / Revised: 24 March 2017 / Accepted: 26 March 2017 / Published online: 13 April 2017

(C) The Author(s) 2017. This article is an open access publication

\begin{abstract}
Antarctic krill (Euphausia superba) play a central role in the food web of the Southern Ocean, forming a link between primary production and large predators. Krill produce large, faecal pellets (FP) which can form a large component of mesopelagic particulate organic carbon (POC) fluxes. However, the patchy distribution of krill swarms, highly variable pellet composition, and variable sinking and attenuation rates means that these episodic, but potentially large, carbon fluxes are difficult to sample or model. We measured particle flux and type using Marine Snow Catchers (MSC) in the marginal ice zone near the South Orkneys, Antarctica. Krill FP were the dominant component of the POC flux in the upper $200 \mathrm{~m}$ (typically 60-85\%). FP sinking velocities measured onboard were highly variable $\left(15-507 \mathrm{~m} \mathrm{~d}^{-1}\right)$ but overall high, with mean equivalent velocities of 172,267 , and $161 \mathrm{~m} \mathrm{~d}^{-1}$ at our three stations. The high numbers of krill FP sinking through the mesopelagic suggest that krill FP can be transferred efficiently and/or that rates of krill FP production are high. We compared our direct MSC-derived estimates of
\end{abstract}

Electronic supplementary material The online version of this article (doi:10.1007/s00300-017-2118-z) contains supplementary material, which is available to authorized users.

A. Belcher

A.Belcher@noc.soton.ac.uk

1 National Oceanography Centre, Southampton SO14 3ZH, UK

2 University of Southampton, Southampton SO14 3ZH, UK

3 British Antarctic Survey, Cambridge CB3 0ET, UK

4 Plymouth Marine Laboratory, Prospect Place, The Hoe, Plymouth PL1 3DH, UK

5 Institute of Marine Research, PO Box 1870, Nordnes, 5817 Bergen, Norway krill FP POC flux (33-154 $\mathrm{mg} \mathrm{C} \mathrm{m}^{-2} \mathrm{~d}^{-1}$ ) and attenuation to estimates of krill FP production based on previous measurements of krill density and literature FP egestion rates, and estimated net krill FP attenuation rates in the upper mesopelagic. Calculated attenuation rates are sensitive to krill densities in the overlying water column but suggest that krill FP could be transferred efficiently through the upper mesopelagic, and, in agreement with our MSC attenuation estimates, could make large contributions to bathypelagic POC fluxes. Our study contrasts with some others which suggest rapid FP attenuation, highlighting the need for further work to constrain attenuation rates and assess how important the contribution of Antarctic krill FP could be to the Southern Ocean biological carbon pump.

Keywords Faecal pellet attenuation - Antarctic krill . Southern Ocean $\cdot$ Carbon flux $\cdot$ Faecal pellet

\section{Introduction}

The Southern Ocean is an important part of the global carbon cycle, with the region south of $40^{\circ} \mathrm{S}(\sim 21 \%$ of the ocean area) estimated to account for $26 \pm 6 \%$ of global export production (defined as the material exported out of the surface ocean) (Primeau et al. 2013). Empirical models suggest that the export of material out of the euphotic zone in the Southern Ocean is efficient but that the transfer of this material through the mesopelagic to the deep ocean is inefficient (Henson et al. 2012). The efficiency with which carbon sinks through the mesopelagic by the biological carbon pump (BCP) is intrinsically linked to levels of atmospheric $\mathrm{CO}_{2}$ (Kwon et al. 2009). Furthermore, the BCP in much of the Southern Ocean does not operate at maximum efficiency as primary production is limited by 
factors including light and iron (Boyd et al. 1999), leading to upwelled nutrients being subducted unused into the ocean interior.

However, this picture conceals the existence of high flux events in some regions of the Southern Ocean, associated with sinking diatoms (e.g., Smetacek 1985; Beaulieu 2002; Roca-Marti et al. 2015), diatom resting spores (Rembauville et al. 2015), enhanced iron supply (e.g., Bidigare et al. 1999; Savoye et al. 2008; Pollard et al. 2009; Smetacek et al. 2012; Jouandet et al. 2014), and the influence of marginal ice zones (Smith and Nelson 1985; Fischer et al. 1988; Buesseler et al. 2001; Cavan et al. 2015). Short-term, high export events can make up a substantial fraction of the annual POC flux. In the Bransfield Strait, 97\% of the annual POC flux to $1588 \mathrm{~m}$ occurred in the two most productive months, associated with Euphausia superba (herein referred to as krill) faecal pellets, (Bodungen et al. 1987; Wefer et al. 1988), yet limited observations in these marginal ice zones mean that krill and their large FP fluxes are not well represented in global biogeochemical models.

Krill are present in high densities in some regions of the Southern Ocean (Atkinson et al. 2008) often occurring in large swarms (Hamner et al. 1989), resulting in the production of large numbers of faecal pellets (FP) some of which can sink rapidly through the water column (Atkinson et al. 2012). Cadée (1992) deployed floating sediment traps for $<1$ day at 50-75 and $150 \mathrm{~m}$ in the Weddell-Scotia Sea, observing that krill FP dominated the trap material. One station in particular (out of 5) exhibited exceptionally high POC fluxes $\left(0.7 \mathrm{~g} \mathrm{C} \mathrm{m}^{-2} \mathrm{~d}^{-1}\right.$ at $75 \mathrm{~m}^{2}$ and $1.5 \mathrm{~g} \mathrm{C} \mathrm{m}^{-2} \mathrm{~d}^{-1}$ at $150 \mathrm{~m}$ ) dominated by krill FP. Cadée (1992) postulated that this large flux event was related to a krill swarm, observed following trap deployment. High krill FP fluxes have also been observed during short-term sediment trap deployments in the Bransfield Strait and Weddell Sea (Dunbar 1984; Bodungen et al. 1987; Bathmann et al. 1991). Similarly, a long-term sediment trap study in Terra Nova Bay in the Ross Sea noted atypically high POC fluxes $(11.13 \mathrm{mg}$ $\mathrm{m}^{-2} \mathrm{~d}^{-1}$ at $95 \mathrm{~m}$ ) in late April-mid June (Accornero et al. 2003), dominated by cylindrical faecal pellets (74-80\% of FP) suggesting that large swarms of euphausiids could also be important contributors to flux in the winter. Observational evidence, therefore, suggests that krill FP can both provide a vehicle for high export of POC, and may also transfer carbon efficiently through the mesopelagic. The South Orkney Islands, situated in the spring-summer marginal ice zone, have been found to exhibit high abundances of krill (Hewitt et al. 2004; Siegel et al. 2004; Atkinson et al. 2008), yet the contribution of their FP to total POC flux there has not been quantified.

Faecal pellets can also be broken up and remineralised by zooplankton and prokaryotes as they sink, decreasing the efficiency of export to the deep sea (e.g., Poulsen and Kiørboe 2005; Iversen and Poulsen 2007; Svensen et al. 2012, 2014) and fragmentation has been suggested to explain high retention of krill FP in the study of González (1992). González (1992) suggests that where krill FP production is high relative to abundances of the zooplankton recycling community, a large percentage of krill FP can pass undisturbed through the mesopelagic zone and reach deep sediment traps. Even if krill FP are grazed upon by deeper dwelling zooplankton populations, this could still result in fresh pellets reaching the deep sea via a cascade effect (Urrere and Knauer 1981; Bodungen et al. 1987; Miquel et al. 2015; Belcher et al. 2017). These uncertainties are compounded by the great variability in sinking rates of the pellets, which depends on diet (Cadée et al. 1992; Atkinson et al. 2012). For instance, the most carbon-rich pellets were found to sink only at an equivalent of a few $10 \mathrm{~s}$ of meters per day, similar to sinking rates of copepod pellets (Atkinson et al. 2012). Because faecal pellets are major vectors of iron and other essential nutrients in addition to carbon (Schmidt et al. 2012, 2016), a better understanding of the balance between retention and export of these particles is needed.

Krill occur mostly in swarms which may produce enough FP to overload the capacity of the zooplankton and microbial communities to graze, fragment, and/or remineralise their FP before they sink to the ocean interior (Atkinson et al. 2012). However, the patchy distribution of krill swarms and the highly variable composition and sinking velocities of the FP (Cadée et al. 1992; Atkinson et al. 2012) mean that their contribution to flux can be episodic and, therefore, difficult to sample. In addition, the complex behaviour of krill makes it difficult to replicate natural conditions in the laboratory (Gibbons et al. 1999; Schmidt and Atkinson 2016; Tarling and Fielding 2016). Overall, this potentially large flux of POC to the mesopelagic of the Southern Ocean is poorly quantified and it is not yet clear from previous studies whether krill FP are transferred efficiently through the upper mesopelagic.

We made measurements of particle flux in the marginal ice zone (MIZ) near the South Orkney Islands during austral spring of two seasons. Our aims were first to quantify the relative proportion of krill pellets in the sinking material, second, to estimate carbon fluxes in the upper mesopelagic, and third, to gauge the vertical transfer efficiency.

\section{Methods}

\section{Study site}

Faecal pellet (FP) fluxes were estimated aboard RRS James Clark Ross during cruises JR291 and JR304 to the Scotia Sea, Antarctica in austral spring 2013 and 2014, 
respectively (Fig. 1a). Samples were obtained in the marginal ice zone near the South Orkney Islands at stations ICE1 $\left(-60.21^{\circ} \mathrm{N},-46.34^{\circ} \mathrm{E}\right)$ and ICE2 $\left(-59.96^{\circ} \mathrm{N}\right.$, $\left.-46.16^{\circ} \mathrm{E}\right)$ during cruise JR291 (01/12/2013) and ICE2 only during cruise JR304 (26/11/2014). There was no ice cover at the time of sampling, but satellite data reveal intermittent ice cover in the weeks prior to sampling (see Figure S1).

\section{Particle collection}

Sinking particles were collected using Marine Snow Catchers (MSCs). These are large (95 L) PVC closing water bottles designed to minimise turbulence (Riley et al. 2012; Cavan et al. 2015; Belcher et al. 2016a, b). Vertical profiles
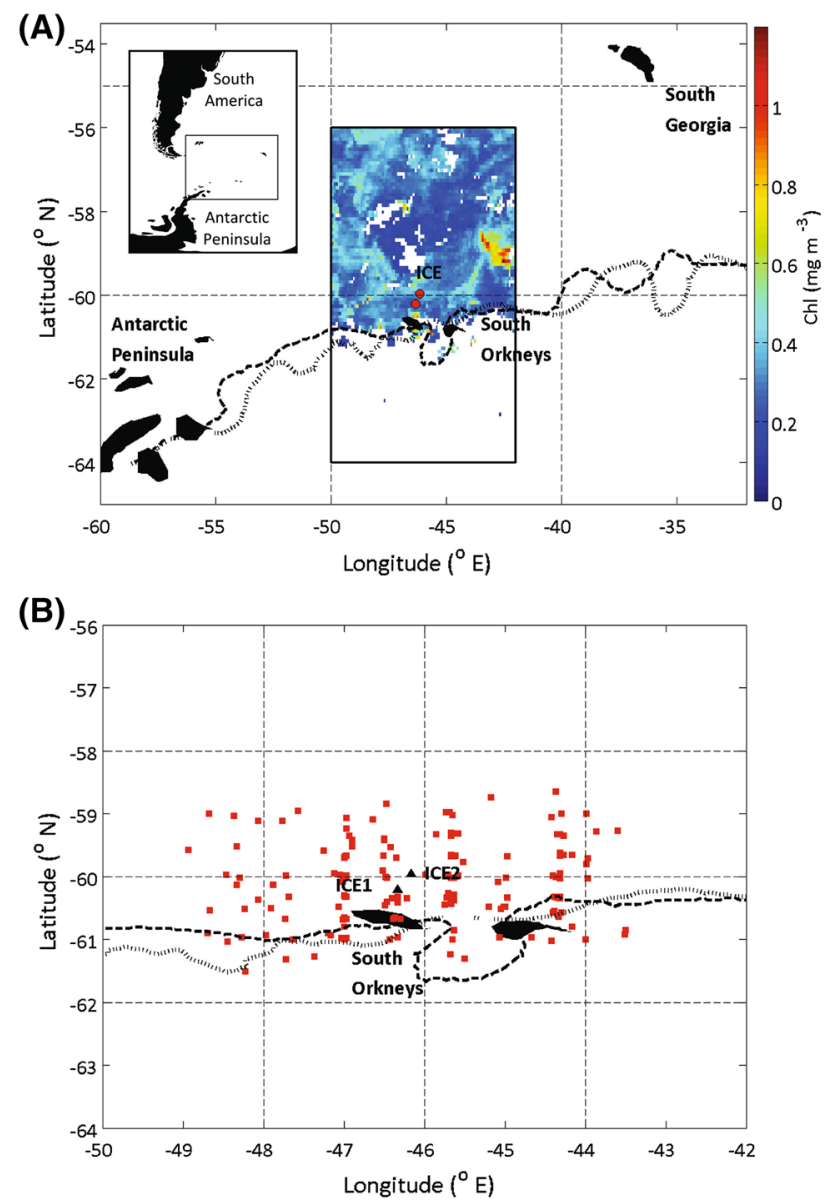

Fig. 1 a ICE station locations (indicated by red circles) overlain on MODIS Aqua satellite chlorophyll $\left(\mathrm{mg} \mathrm{m}^{-3}\right)$ for December 2014 (chlorophyll shown for region covered by b). Top left inset shows larger regional scale for context. Position of ice edge on December 14th 2014 (thick black dashed line) and December 3rd 2013 (black dotted line) (OSTIA sea ice data). b Location of krill density samples taken from KRILLBASE for stations ICE1 and ICE2 (red squares). ICE1 and ICE2 stations are shown by large black triangles. (Color figure online) of temperature, salinity, and fluorescence were taken prior to MSC deployments using a conductivity-temperature-depth (CTD) unit (Seabird 9Plus with SBE32 carousel) to define the base of the mixed layer and thus MSC deployment depths. To assess the attenuation of FP in the upper mesopelagic, two MSCs were deployed in quick succession at 10 and $110 \mathrm{~m}$ below the base of the mixed layer depth (MLD), herein referred to as MLD+10 and MLD +110 , respectively. MSCs were deployed during the day at ICE2 during both cruises and, due to logistical constraints, $1-1.5 \mathrm{~h}$ after sunset at ICE1.

Following deployment and recovery of the MSCs (which typically took $0.25-0.5 \mathrm{~h}$ ), they were left on deck for a $2 \mathrm{~h}$ settling period, before draining the bottle and carefully removing the particle collector tray (divided into four quadrants for sample splitting) from the base which, was stored at $2-4{ }^{\circ} \mathrm{C}$ for further analysis. Fast-sinking particles are operationally defined here as particles sinking fast enough to reach the base of the MSC during this time (Riley et al. 2012), which, given the height of the snow catcher of $1.53 \mathrm{~m}$, requires a minimum sinking rate of $18.4 \mathrm{~m} \mathrm{~d}^{-1}$ for particles to reach the base of the MSC. This settling period is more than sufficient to allow FP to reach the tray based on previous direct measurements of FP sinking velocity in the Southern Ocean which range from 27 to $1218 \mathrm{~m} \mathrm{~d}^{-1}$ (Atkinson et al. 2012; Cavan et al. 2015; Belcher et al. 2016b).

\section{Particle type}

During both JR304 and JR291, 1-4 sample splits were photographed using an Olympus SZX16 microscope with Canon EOS 60D camera and Olympus BX-SZX Micro Cam and particles classified into: krill FP, other FP, phytodetrital aggregates, phytoplankton cells, and other phytodetritus. Phytodetrital aggregates were identified as aggregations $>0.1 \mathrm{~mm}$ equivalent spherical diameter (ESD) containing phytoplankton cells and other phytodetrital material. Individual particle dimensions were measured using ImageJ and volumes calculated using formulae for a sphere, ellipsoid, or cylinder depending on particle shape. E. superba FP were identified via comparison with freshly egested FP (Belcher et al. 2016b). FP carbon contents were calculated from measured volumes based on direct measurements at the study site (see in the following). Conversions from volume to carbon for phytoplankton cells were based on the equation of Menden-Deuer and Lessard (2000) for diatoms $>3000 \mu \mathrm{m}^{3}$ : $\log \left(\mathrm{pgC}_{\text {cell }}{ }^{-1}\right)=-0.933+0.881$ $\log \left[\operatorname{volume}\left(\mu \mathrm{m}^{3}\right)\right]$, and conversions from phytodetrital aggregate and other phytodetrital material volume to carbon based on the equation of Alldredge (1998): $\mu \mathrm{C}_{\mathrm{agg}}{ }^{-1}=0.99$ [volume $\left(\mathrm{mm}^{3}\right)^{0.52}$ ]. The use of literature conversions introduces uncertainties into our results, but 
our use is consistent with previous studies (e.g., Alldredge 1998; Laurenceau-Cornec et al. 2015). Furthermore, we are more interested here in determining the relative reduction, rather than the absolute amount, of flux between depths, so reducing the effect of these uncertainties.

In this study, we focus on FP to assess the importance of krill FP to total POC flux. All FP were counted and their length and widths measured manually using ImageJ. Equivalent spherical diameters (ESD) were also calculated. Volumes were calculated from these measurements using the formula for a cylinder, and FP carbon content calculated according to an FP carbon to volume ratio of $0.032 \mathrm{mg} \mathrm{C}$ $\mathrm{mm}^{-3}$ (range $0.022-0.042 \mathrm{mg} \mathrm{C} \mathrm{mm}^{-3}$ ) based on measurements made on FP (10-15 per replicate filter) collected from Bongo nets at ICE2 during JR304 (see Belcher et al. (2016b) for details of Bongo net deployments). FP were rinsed three times in filtered sea water, photographed under a microscope to obtain size measurements, filtered onto pre-combusted glass fibre filters $(25 \mathrm{~mm}$ diameter $\mathrm{GF} / \mathrm{F}$, Whatman), and oven dried at $50^{\circ} \mathrm{C}$ for analysis of POC. Filters were then fumed with $37 \% \mathrm{HCl}$ in a vacuum desiccator for $24 \mathrm{~h}$, and dried for $24 \mathrm{~h}$ at $50^{\circ} \mathrm{C}$, before placing both filters and filter blanks in pre-combusted $\left(450^{\circ} \mathrm{C}\right.$, $24 \mathrm{~h}$ ) tin capsules as in Hilton et al. (1986), and measuring POC in a CE-440 Elemental analyser (Exeter Analytical.285 Inc).

\section{Faecal pellet flux}

Following calculation of the total mass $(m)$ of sinking FP carbon in the MSC, FP flux $(F)$ was calculated as follows:

$F\left(\mathrm{mg} \mathrm{C} \mathrm{m}^{-2} \mathrm{~d}^{-1}\right)=\frac{m}{A} \times \frac{w}{h}$,

where $A$ refers to the area of the MSC opening based on inner MSC diameter, $w$ the measured sinking velocity ( $\mathrm{m}$ $\mathrm{d}^{-1}$ ) from laboratory measurements, and $h$ the height of the snow catcher $(1.53 \mathrm{~m})$. Krill FP flux was calculated based on krill FP sinking velocities only.

During JR291, FP sinking velocities were measured in a temperature controlled laboratory (at $2{ }^{\circ} \mathrm{C}$ ) using a $1 \mathrm{~L}$ graduated glass cylinder $(7 \mathrm{~cm}$ diameter). Laboratory temperatures were at most $\sim 3^{\circ} \mathrm{C}$ warmer than in situ water temperatures which could result in overestimations of sinking speed of up to $15 \%$ based on theoretical calculations of the effects of viscosity (Taucher et al. 2014). However, observational studies have not observed differences in sinking velocity at different temperatures (Trull et al. 2008; Iversen and Ploug 2013), so this small difference in temperature is unlikely to bias our measurements. FP were carefully removed from the particle collector tray using a plastic pipette and transferred into a graduated cylinder which was filled with seawater collected from the MSC at the ICE station. The sinking velocity of each FP was calculated from the average of the time taken to sink past two marked distances $(10 \mathrm{~cm}$ apart), with the starting point more than $10 \mathrm{~cm}$ from the water surface. Results were discarded where the walls of the cylinder were observed to interfere with the sinking FP. During JR304, sinking velocities were measured in a temperature controlled $\left(\right.$ at $\left.4{ }^{\circ} \mathrm{C}\right)$ flow chamber system (Ploug and Jorgensen 1999) containing filtered sea water $(0.22 \mu \mathrm{m}$ filter $)$ taken from the MSC deployed at ICE stations. FP were placed carefully in the chamber and three measurements of the sinking velocity made for each FP by suspending the FP with an upward flow (Ploug and Jorgensen 1999). Sinking velocity measurements were limited to those particles visible by eye (ESD $>0.15 \mathrm{~mm}$ ). Sinking velocities measured during JR291 and JR304 by these two different methods were not significantly different (Student's $t$ test, $p=0.2$ ), suggesting that the use of two different methods to measure sinking velocity did not bias our results.

\section{Faecal pellet flux attenuation}

The rate of mesopelagic FP flux attenuation was assessed by fitting a power-law function (Martin et al. 1987) to the FP flux data:

$F_{z}=F_{z_{0}} \times\left(z / z_{0}\right)^{-b}$,

where $z$ is the depth of the flux (m), and $F_{z 0}$ is flux (mg C $\mathrm{m}^{-2} \mathrm{~d}^{-1}$ ) at the reference depth. A high absolute value of $b$ corresponds to high attenuation (shallow remineralisation) and vice versa. We calculate attenuation rates through the mesopelagic (between MLD +10 and MLD +110) based on our MSC estimates of FP flux which we define as $b_{\mathrm{MSC}}$.

\section{Results}

\section{Oceanographic setting}

Surface temperatures were consistent between sites and between years ranging from -0.83 to $-0.59^{\circ} \mathrm{C}$ (Fig. 2). At ICE1 JR291 and ICE2 JR304, chlorophyll a peaked at $0.5 \mathrm{mg} \mathrm{m}^{-3}$ at $30 \mathrm{~m}$. Chlorophyll a was elevated at ICE2 JR291, peaking at $1 \mathrm{mg} \mathrm{m}^{-3}$ at $38 \mathrm{~m}$ (Fig. 2).

\section{Particle flux and type}

FP were the dominant component of the flux at all stations (Fig. 3), accounting for $85.0-93.1 \%$ of the sinking POC at MLD+10, and $93-99 \%$ at MLD +110 . As we were only able to directly measure the POC content for FP, there is some uncertainty in these percentages; however, 


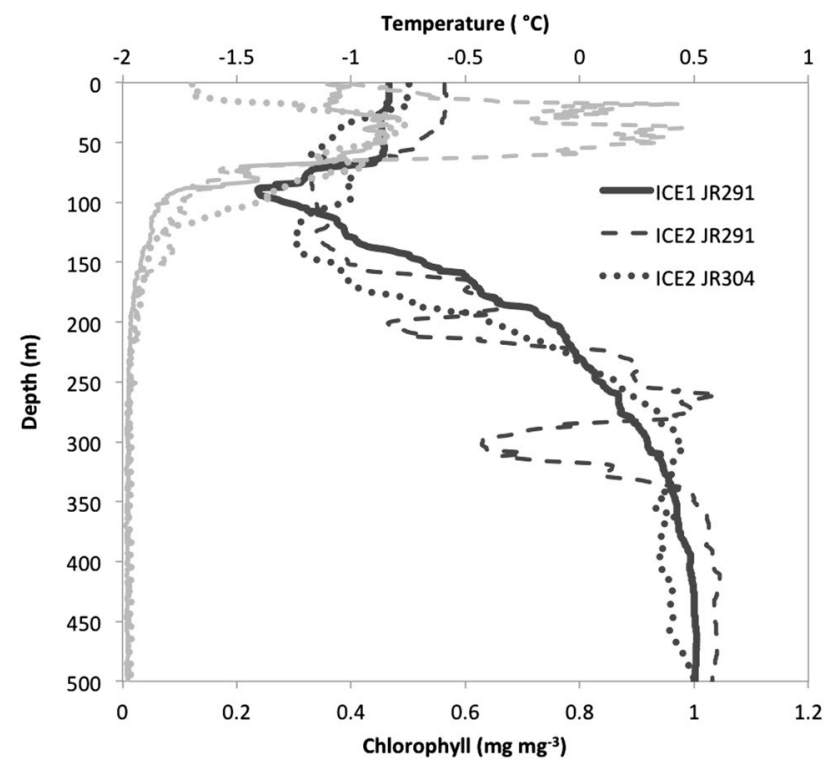

Fig. 2 Vertical profiles of temperature (dark grey lines) and chlorophyll a (light grey lines) from CTD deployments at ICE1 (solid line), and ICE2 (dashed line), during cruises JR291, and ICE2 during JR304 (dotted line)

even in terms of numerical abundance, FP accounted for $52-58 \%$ of total sinking particle abundance at MLD +10 and $56-95 \%$ at MLD+110. Most of these FP belonged to Antarctic krill, with the exception of the MLD+10 sample at ICE2 JR291, where krill FP accounted for $43.6 \%$ of the FP POC. The remaining FP were smaller cylindrical pellets that may originate from copepods or smaller euphausiid species. Krill FP were on average 0.15, 0.13, and $0.14 \mathrm{~mm}$ in width at MLD+10, and $0.15,0.17$, and $0.16 \mathrm{~mm}$ at MLD+110 at ICE1 JR291, ICE2 JR291, and ICE2 JR304, respectively. Krill FP lengths were on average 1.03, 0.70, and $1.28 \mathrm{~mm}$ at MLD +10 , and $0.69,0.91$, and $0.90 \mathrm{~mm}$ at MLD+110 at ICE1 JR291, ICE2 JR291, and ICE2 JR304, respectively. However, as krill FP are produced in strings which can be easily broken, we calculate FP fluxes in terms of carbon rather than absolute abundance.

Median krill FP sinking velocities were 172, 267, and $161 \mathrm{~m} \mathrm{~d}^{-1}$ at ICE1 JR291, ICE2 JR291, and ICE2 JR304, respectively, ranging from 15 to $507 \mathrm{~m} \mathrm{~d}^{-1}$ ( $n=54$, Fig. 4). A Student's $t$ test on sinking velocities at each site revealed no statistically significant differences between means $(p>0.05)$. Krill FP fluxes (Fig. 5) were very similar at ICE1 JR291 and ICE2 JR304 at both MLD+10 (66.7 and $\left.68.0 \mathrm{mg} \mathrm{C} \mathrm{m}^{-2} \mathrm{~d}^{-1}\right)$ and MLD+110 (75.5 and $77.3 \mathrm{mg}$ $\mathrm{C} \mathrm{m} \mathrm{d}^{-1}$ ), showing a slight increase in flux with depth (Table 1). Conversely, at ICE2 JR291, a large increase in krill FP flux was observed between MLD+10 and MLD+110 (33.0 to $154.1 \mathrm{mg} \mathrm{C} \mathrm{m}^{-2} \mathrm{~d}^{-1}$ ).
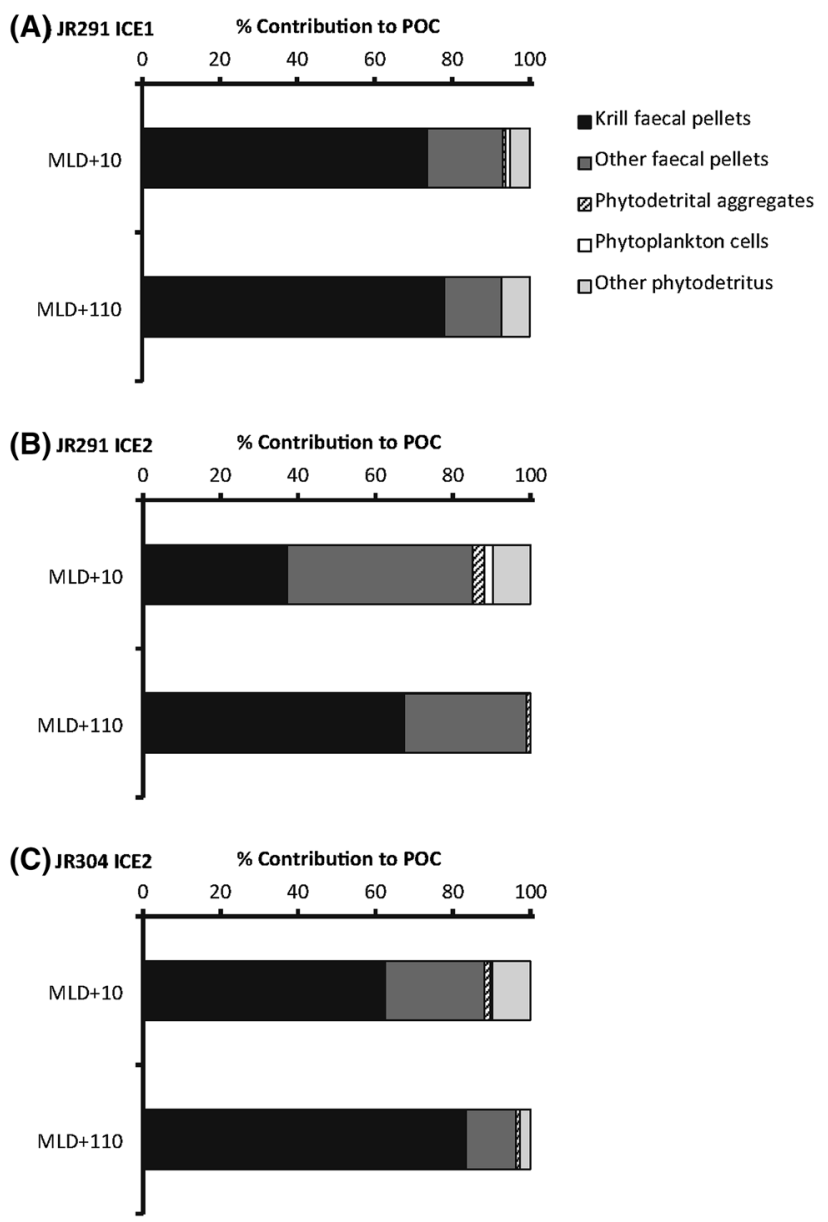

Fig. 3 Type of fast-sinking particulate organic carbon at (a) ICE1 JR291, (b) ICE2 JR291, and (c) ICE2 JR304 stations based on microscope analysis and calculated carbon content. Black krill faecal pellets, dark grey other faecal pellets, hashed phytodetrital aggregates, white phytoplankton cells and light grey other phytodetritus

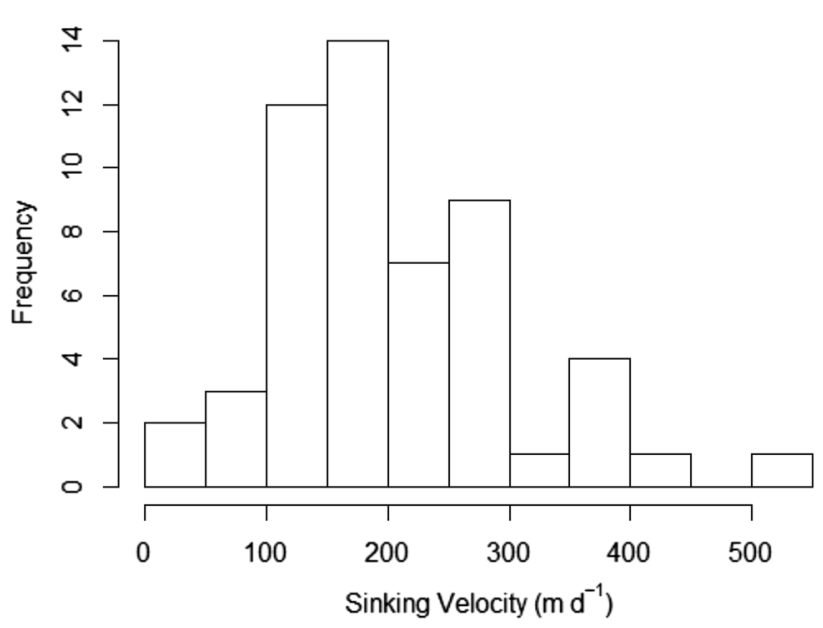

Fig. 4 Distribution of krill faecal pellet sinking velocities $\left(\mathrm{m} \mathrm{d}^{-1}\right)$ measured at stations ICE1 and ICE2 during JR291 and JR304 


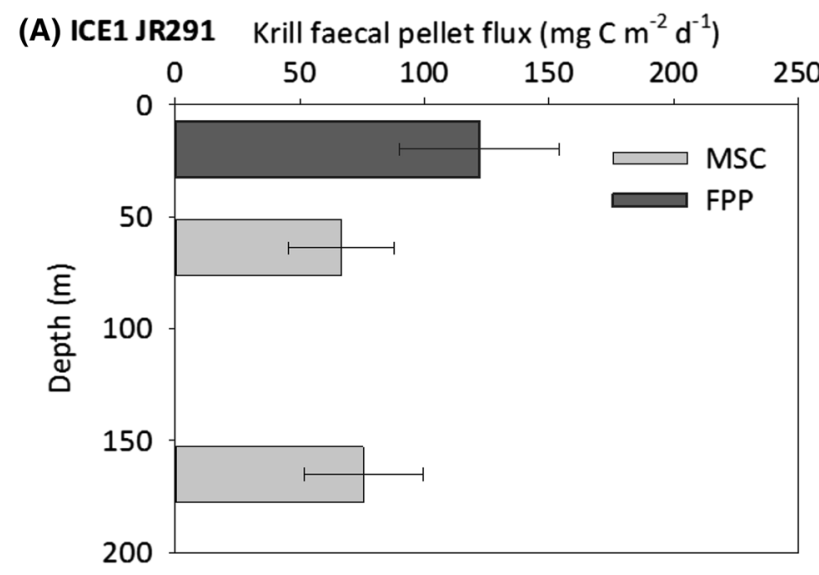

(B) ICE2 JR291

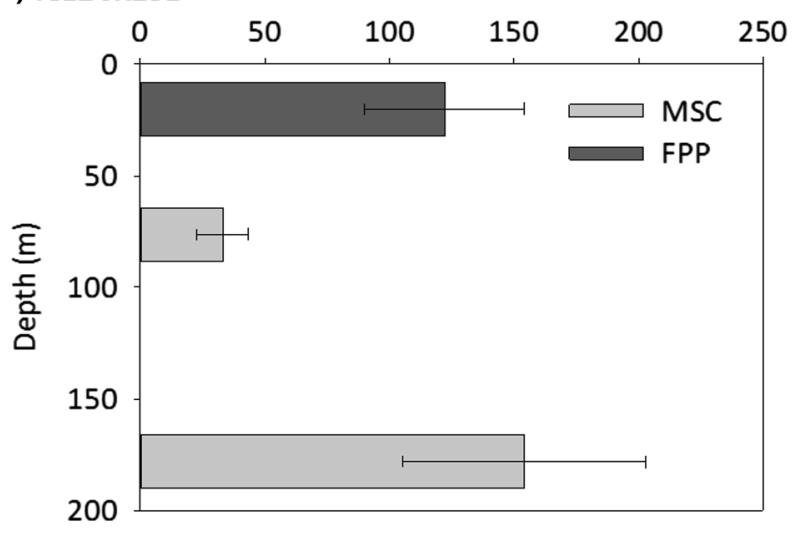

(C) ICE2 JR304

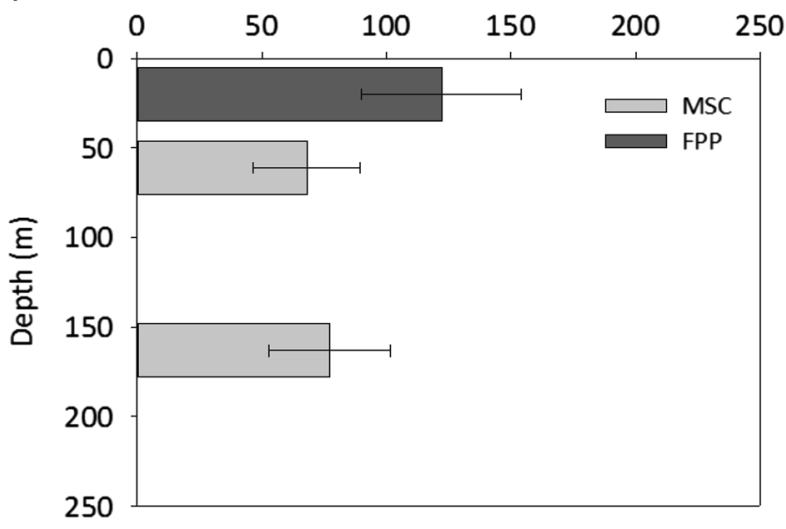

Fig. 5 Krill faecal pellet (FP) fluxes estimated in the South Orkneys at (a) ICE1 JR291, (b) ICE2 JR291, and (c) ICE2 JR304. Krill FP fluxes estimated in Marine Snow Catchers (MSC) at the mixed layer depth $+10 \mathrm{~m}$ and the mixed layer depth $+110 \mathrm{~m}$ are shown by light grey bars (error bars show maximum and minimum fluxes based on the range of measured FP particulate organic carbon contents). Predicted krill FP production (FPP) at a depth of $20 \mathrm{~m}$ is shown by dark grey bars based on an egestion rate of $3.2 \mathrm{mg} \mathrm{C}$ ind $^{-1} \mathrm{~d}^{-1}$ from Clarke et al. (1988), with error bars showing maximum and minimum fluxes based on krill densities from KRILLBASE (mean $\pm 1 \mathrm{SE})$

\section{Faecal pellet flux attenuation}

At all sites, we observed an increase in krill FP between MLD + 10 and MLD+110 in MSC samples resulting in negative attenuation coefficients $\left(b_{\mathrm{MSC}}\right)$ of $-0.13,-1.81$, and -0.13 at ICE1 JR291, ICE2 JR291, and ICE2 JR304, respectively.

\section{Discussion}

\section{Faecal pellet flux}

Krill FP were the dominant component of the POC flux at ICE1 and ICE2 stations (Fig. 3) highlighting their importance for the transfer of POC through the upper mesopelagic layer in this MIZ region. These high fluxes may, at least in part, be driven by the high FP sinking velocities that we measured. Our MSC estimated krill FP fluxes at ICE1 and ICE2 (75.5-154.1 $\left.\mathrm{mg} \mathrm{C} \mathrm{m}^{-2} \mathrm{~d}^{-1}\right)$ are high compared to fluxes of cylindrical FP (presumed from krill) measured in sediment traps deployed on the Western Antarctic Peninsula at $170 \mathrm{~m}$ in summer $\left(11.36 \mathrm{mg} \mathrm{C} \mathrm{m}^{-2}\right.$ $\mathrm{d}^{-1}$ ) (Gleiber et al. 2012). However, Gleiber et al. (2012) also recorded peaks in cylindrical krill FP flux of up to $125.5 \mathrm{mg} \mathrm{C} \mathrm{m}^{-2} \mathrm{~d}^{-1}$ in summer. Krill FP fluxes compare quite well to measurements made at $50 \mathrm{~m}$ in the MIZ of the Scotia Sea [FP fluxes of $\sim 60 \mathrm{mg} \mathrm{C} \mathrm{m}^{-2} \mathrm{~d}^{-1}$, dominated by krill (Cavan et al. 2015)]. Our study, therefore, agrees with previous studies that Antarctic krill FP can make a major contribution to POC fluxes in the upper mesopelagic in the MIZ in spring and summer (75-100\%, Gleiber et al. 2012; Cavan et al. 2015). We, therefore, suggest that areas of high krill density warrant more detailed research to assess their contribution to bathypelagic POC fluxes and long-term carbon sequestration.

\section{Faecal pellet production and attenuation}

We observed an increase in krill FP flux between MLD +10 and MLD +110 (negative attenuation) at all sites suggesting non-steady-state FP production, minimal attenuation with depth, FP production between the measurement depths, and/or inputs via lateral advection. Satellite-derived surface current data (OSCAR, 1/3 degree grid, 5 day resolution) suggest that surface velocities were $<0.15 \mathrm{~m} \mathrm{~s}^{-1}$ at the ICE stations during our study period, and thus, lateral advection was likely small.

At ICE1 JR291 and ICE2 JR304, only a slight increase in krill FP with depth was observed $\left(b_{\mathrm{MSC}}=-0.13\right)$, which we suggest is a result of low attenuation and an additional input via satiation sinking (i.e., sinking as a result of being full), as supported by previous studies in the region (Lancraft et al. 1991; Tarling and Johnson 2001). Tarling and Johnson (2001) estimate that krill spent $40 \%$ of the nighttime period below the surface mixed layer due to satiation sinking, and egest $1.7 \mathrm{mg} \mathrm{C}$ ind. ${ }^{-1} \mathrm{~d}^{-1}$ during this time. 
Table 1 Marine Snow Catcher deployment table for cruises JR291 and JR304 to the South Orkneys, Antarctica, showing total faecal pellet (FP) and krill FP carbon fluxes

\begin{tabular}{lllccc}
\hline Site & Date & Time (GMT) & Depth $(\mathrm{m})$ & $\begin{array}{l}\text { FP flux (mg C } \\
\left.\mathrm{m}^{-2} \mathrm{~d}^{-1}\right)\end{array}$ & $\begin{array}{l}\text { Krill FP Flux } \\
\left(\mathrm{mg} \mathrm{C} \mathrm{m}^{-2}\right. \\
\left.\mathrm{d}^{-1}\right)\end{array}$ \\
\hline ICE1 JR291 & $01 / 12 / 2013$ & $01: 45$ & 64 & 88.5 & 66.7 \\
& & $02: 21$ & 165 & 94.3 & 75.5 \\
ICE2 JR291 & $01 / 12 / 2013$ & $12: 58$ & 76 & 74.2 & 33.0 \\
& & $13: 37$ & 178 & 221.4 & 154.1 \\
ICE2 JR304 & $26 / 11 / 2014$ & $16: 44$ & 61 & 92.9 & 68.0 \\
& & $17: 12$ & 163 & 86.1 & 77.3 \\
\hline
\end{tabular}

This would equate to $81.6 \mathrm{mg} \mathrm{C} \mathrm{m}^{-2} \mathrm{~d}^{-1}$ for a typical mean krill density of 38 ind. $\mathrm{m}^{-2}$. Tarling and Johnson (2001) estimate that krill can descend 9-46 m during satiation sinking, and with most krill in the region occurring within the upper $50 \mathrm{~m}$ in spring (Fielding et al. 2012), this could account for our observed increase in FP flux between sampling depths.

FP production at depth due to satiation sinking cannot, however, explain the observed fourfold increase in krill FP between MLD+10 and MLD+110 at ICE2 JR291, even in the unlikely situation that no remineralisation of the FP produced during satiation sinking occurred. We hypothesise that FP production between MLD +10 and MLD +110 due to diel vertical migration (DVM), short-term intermittent vertical migrations (Godlewska and Klusek 1987) or simply a deeper distribution of krill, could account for increases in FP abundance with depth at ICE2 JR291. ICE2 JR291 was sampled during the day (10:58-11:37 local time), and if gut passage times were sufficient, then DVM may explain the high FP fluxes at this site. However, ICE2 JR304 was also sampled during the day (14:44-15:12 local time), and similarly, large increases in FP fluxes with depth were not observed. Most krill swarms in the region of our study site occur at depths $<60 \mathrm{~m}$ in spring (Fielding et al. 2012) and in late spring-early summer DVM of krill are small in the South Orkney Islands area (Taki et al. 2005). We, therefore, consider it unlikely that DVM alone could result in the large increase in FP at depth that we observed at $178 \mathrm{~m}$ at ICE2 JR291.

Considering the lower percentage contribution of krill FP at MLD +10 at this site compared to ICE1 and ICE2 JR304 (43.6\% compared to $>85 \%$, Fig. 3), this apparent increase with depth may reflect non-steady-state FP production, with increased production (perhaps associated with the increased chlorophyll concentration (Fig. 2), or with the passing of a krill swarm) prior to sampling resulting in higher FP fluxes at MLD +110 as the FP sank through the ocean. Although dedicated acoustic transects were not carried out during our study preventing the calculation of krill densities at the time of sampling, the shipboard EK60 $120 \mathrm{kHz}$ echosounder highlights that a number of large krill swarms (two orders of magnitude larger in area than observed at our other study sites) were present, at mean depths of $<50 \mathrm{~m}$, up to $5 \mathrm{~h}$ prior to sampling at ICE2 JR291. Acoustic observations, therefore, support our hypothesis that the passing of krill swarms can drive higher fluxes of FP through the mesopelagic as also found in other regions (Cadée 1992).

The high fluxes of krill FP measured at both MLD +10 and MLD +110 at all stations (Table 1) could be due to high FP production (FPP) at the depth of krill feeding and/ or due to low attenuation. We have made preliminary estimates of krill FPP based on krill densities obtained from the literature (Atkinson et al. 2008; Fielding et al. 2012; Skaret et al. 2015; Table 2), and krill FP egestion rates measured by Clarke et al. (1988). Clarke et al. (1988) carried out FP egestion experiments on E. superba collected from Arthur Harbour, on Anvers Island, Antarctica, as well as the Bransfield Strait, Antarctica. They measured a range in egestion rates $\left(0.25-2.35 \mathrm{mg}\right.$ FP dry weight ind $\left.^{-1} \mathrm{~h}^{-1}\right)$, giving an egestion of $0.7-6.3 \mathrm{mg} \mathrm{C}$ ind $^{-1} \mathrm{~d}^{-1}$ assuming an organic $\mathrm{C}$ content of $11.15 \%$ dry weight [average of open ocean sites (8.1-13.7\%) from Clarke et al. (1988)]. We take their 'representative' egestion rate of $1.2 \mathrm{mg}$ FP dry weight ind $^{-1} \mathrm{~h}^{-1}$, giving a rate of $3.2 \mathrm{mg} \mathrm{C}$ ind $^{-1} \mathrm{~d}^{-1}$. The range in literature estimates of krill density is high, 28-2009 ind. $\mathrm{m}^{-3}$ (Table 2), highlighting the patchy nature of krill swarms. The bulk of estimates lies between 28 and 700 ind. $\mathrm{m}^{-3}$ (Atkinson et al. 2008; Fielding et al. 2012), with one high record of 1128 ind. $\mathrm{m}^{-3}$ from the KRILLBASE database of Atkinson et al. (2008) and the high value of 2009 ind. $\mathrm{m}^{-3}$ from the acoustic data of Skaret et al. (2015). Applying an egestion rate of $3.2 \mathrm{mg} \mathrm{C}$ ind ${ }^{-1} \mathrm{~d}^{-1}$ to krill densities of 28-700 ind. $\mathrm{m}^{-3}$ gives FPP of 90-2248 mg C $\mathrm{m}^{-2} \mathrm{~d}^{-1}$, highlighting that FPP could indeed be very high. When high krill densities occur, this could drive much higher FP fluxes to the mesopelagic without the need for low rates of attenuation, a scenario which may have been captured by our sampling at ICE2 JR291 (Fig. 5b). The apparent negative attenuation rate (i.e., an increase in FP flux with depth) calculated at this station may, therefore, be explained by the episodic passing of a krill swarm prior to 
Table 2 Estimates of krill density in the study region of the South Orkneys based on previous studies

\begin{tabular}{|c|c|c|c|c|c|}
\hline Data Type & Source & Region & Year & Season & $\begin{array}{l}\text { Mean krill } \\
\text { density } \\
\left(\text { ind. } \mathrm{m}^{-2}\right)^{\mathrm{a}}\end{array}$ \\
\hline Net (KRILLBASE) ${ }^{\mathrm{c}}$ & Atkinson et al. (2008) & $300 \times 300 \mathrm{~km}$ box centred on ICE1 & 1926-2004 & $\begin{array}{l}\text { Standardised to } \\
\text { January }\end{array}$ & $\begin{array}{l}38( \pm 10 \\
0-1128)^{\mathrm{b}}\end{array}$ \\
\hline \multirow[t]{4}{*}{ Acoustic $^{d}$} & \multirow[t]{4}{*}{ Fielding et al. (2012) } & \multirow[t]{2}{*}{ South Orkneys: their Sp3 } & 2006 & November & 700 \\
\hline & & & 2008 & January & 122 \\
\hline & & \multirow[t]{2}{*}{ South Orkneys: their Sp4 } & 2006 & November & 28 \\
\hline & & & 2008 & January & 36 \\
\hline Acoustic $^{\mathrm{e}}$ & $\begin{array}{l}\text { Resampled from Skaret } \\
\text { et al. (2015) }\end{array}$ & $25 \mathrm{~km}$ to the north and south of ICE1 & 2014 & January & 2009 \\
\hline
\end{tabular}

\footnotetext{
${ }^{a}$ Acoustic estimates have been converted using size-weight conversions (Kils 1981)

${ }^{\mathrm{b}}$ Mean ( \pm standard error, range)

${ }^{\mathrm{c}}$ A historical database (KRILLBASE) of 9922 individual net hauls taken in the Southern Ocean since 1926

d $50 \mathrm{~km}$ surveys carried out close to the ICE stations by the RRS James Clark Ross using a Simrad EK600 echosounder (38, 120, 200 kHz)

${ }^{\text {e}}$ Surveys were carried out by the FV Saga Sea in the region of the South Orkneys using a 38 and $120 \mathrm{kHz}$ echo sounder; we resampled the transect line nearest to our study site (transect following $-46.5^{\circ} \mathrm{E}$ ), analysing sample bins with the range of $25 \mathrm{~km}$ to the north and south of the ICE1 station
}

the time of sampling (supported by the semi-quantitative shipboard acoustic observations described above). This site may, therefore, not represent steady-state conditions, reducing the validity of estimates of attenuation at this site.

Based on the above calculation of FPP, we estimate the possible 'net' attenuation between FP production at a depth of $20 \mathrm{~m}$ [based on mean krill swarm depths of $18.9 \mathrm{~m}$ measured in the southern Scotia Sea in spring (Fielding et al. 2012)] and our measurements of krill FP flux at MLD +110 at ICE1 JR291 and ICE2 JR304, which we define here as $b_{\mathrm{FPP}}$. We do not include the FP flux measured at MLD +110 during ICE2 JR291 in our calculations of $b_{\mathrm{FPP}}$ to avoid bias due to potential non-steady-state conditions. The calculated range in $b_{\mathrm{FPP}}$ of $0.07-1.61$ highlights that, depending on the krill density, it is possible that net attenuation rates could be very low, but there could also be scenarios, where attenuation rates are high.

\section{Sensitivity analysis}

Considering the range in possible krill densities and egestion rates, we conduct a sensitivity analysis to assess the validity of our estimates of krill density, FPP, and $b_{\mathrm{FPP}}$. Accurate measurements of krill FP egestion rates are not easy to obtain due to the complex behaviour of krill and the difficulty in replicating natural conditions (Schmidt and Atkinson 2016; Tarling and Fielding 2016). We did not directly measure krill FP egestion rates which increase the uncertainty in our calculated $b_{\mathrm{FPP}}$. We conduct a sensitivity analysis (Table 3) using the range of FP egestion rates measured by Clarke et al. (1988) (0.7-6.3 $\mathrm{mg} \mathrm{C}$ ind $\left.^{-1} \mathrm{~d}^{-1}\right)$, which also encompasses other krill FP egestion estimates from the literature [0.75-2.5 $\mathrm{mg} \mathrm{C}$ ind ${ }^{-1} \mathrm{~d}^{-1}$, Nordhausen and Huntley (1990), Pakhomov et al. (1997), Atkinson et al. (2012)]. This results in $b_{\mathrm{FPP}}$ of between -0.73 and 0.87 for minimum FPP rates, and between 0.33 and 1.92 for maximum FPP rates based on mean KRILLBASE krill densities and the acoustic estimates of Fielding et al. (2012). However, using our highest krill density estimate from Skaret et al. (2015), we calculate attenuation rates of 1.36 and 2.43 based on minimum and maximum FPP, respectively. The density of krill is, therefore, the largest uncertainty in our estimates of FPP and $b_{\mathrm{FPP}}$.

Clarke et al. (1988) measured a large variation in the rate of total FP egestion, but found that the loss of organic material showed no significant daily variation during experiments in summer, increasing our confidence in the value for FP carbon content used here. However, Manno et al. (2015) observed changes in FP carbon content seasonally and Atkinson et al. (2012) found that egestion rates and absorption efficiencies varied with diet and food availability, measuring carbon contents of $3.8-17.1 \%$ of the FP dry mass in the Scotia Sea in spring. Using this range in FP carbon content and the aforementioned range in FP egestion rates, we calculate FP carbon egestion rates ranging from 0.23 to $9.64 \mathrm{mg} \mathrm{C} \mathrm{m}^{-2} \mathrm{~d}^{-1}$. Again, this produces a wide range in attenuation rates (Table 3), highlighting the need for more constrained measurements of krill density and krill FP production alongside krill FP measurements at depth to determine just how low these attenuation rates are. 
Table 3 Sensitivity analysis of attenuation rates $\left(\mathrm{b}_{\mathrm{FPP}}\right)$ at ICE1 JR291 and ICE2 JR304

\begin{tabular}{llllr}
\hline Site & Krill abundance $\left(\right.$ ind. $\left.\mathrm{m}^{-2}\right)$ & $\begin{array}{l}\text { Krill egestion rate } \\
\left(\mathrm{mg} \mathrm{C} \text { ind }^{-1} \mathrm{~d}^{-1}\right)\end{array}$ & $\begin{array}{l}\text { Krill FP carbon } \\
\text { content }(\% \text { of } \\
\text { DW) }\end{array}$ & Attenuation rate $\left(b_{\mathrm{FPP}}\right)^{\mathrm{d}}$ \\
\hline ICE1 JR291 & $28-700(2009)$ & 0.67 & $11.15^{\mathrm{a}}$ & $-0.73-0.87(1.36)$ \\
& $28-700(2009)$ & 6.29 & $11.15^{\mathrm{a}}$ & $0.33-1.92(2.43)$ \\
& $28-700(2009)$ & $0.23^{\mathrm{b}}$ & 3.8 & $-1.17-0.36(0.86)$ \\
& $28-700(2009)$ & $9.64^{\mathrm{c}}$ & 17.1 & $0.60-2.13(2.63)$ \\
ICE2 JR304 & $28-700(2009)$ & 0.67 & $11.15^{\mathrm{a}}$ & $-0.75-0.86(1.36)$ \\
& $28-700(2009)$ & 6.29 & $11.15^{\mathrm{a}}$ & $0.32-1.93(2.43)$ \\
& $28-700(2009)$ & $0.23^{\mathrm{b}}$ & 3.8 & $-1.18-0.35(0.85)$ \\
& $28-700(2009)$ & $9.64^{\mathrm{c}}$ & 17.1 & $0.60-2.13(2.63)$ \\
\hline
\end{tabular}

Attenuation rates have been calculated based on the range of krill abundances (ind. $\mathrm{m}^{-2}$ ) from KRILLBASE (mean $\pm 1 \mathrm{SE}$ ) and acoustic estimates from Fielding et al. (2012), the range of faecal pellet egestion rates (mg C ind ${ }^{-1} \mathrm{~d}^{-1}$ ) from Clarke et al. (1988), and krill faecal pellet (FP) carbon contents from Clarke et al. (1988) and Atkinson et al. (2012). We also give attenuation rates based on the very high krill density estimate from summer 2014 krill density data (Skaret et al. 2015), shown in brackets

${ }^{a}$ Average of open ocean sites (8.1-13.7\%) from Clarke et al. (1988)

${ }^{\mathrm{b}}$ Based on minimum egestion rates (Clarke et al. 1988) and minimum FP carbon contents measured by Atkinson et al. (2012) in the Scotia Sea in spring

${ }^{\mathrm{c}}$ Based on maximum egestion rates (Clarke et al. 1988) and maximum FP carbon contents measured by Atkinson et al. (2012) in the Scotia Sea in spring

${ }^{\mathrm{d}}$ Attenuation rates calculated between our predicted FPP at a depth of $20 \mathrm{~m}$ [based on mean krill swarm depths of $18.9 \mathrm{~m}$ measured in the southern Scotia Sea in spring (Fielding et al. 2012)] and our estimated FP fluxes at the mixed layer depth $+110 \mathrm{~m}$. We exclude the very high flux value of ICE2 JR291 (likely due to non-steady-state conditions and the passing of a krill swarm, see "Discussion")

\section{Krill FP attenuation in the Southern Ocean}

Although high fluxes of krill FP have been noted elsewhere before, these have often only been measured at one depth so prohibiting quantification of attenuation rate (Dunbar 1984; Bathmann et al. 1991; Gleiber et al. 2012), or visual observations of krill FP have been made rather than measuring FP carbon fluxes directly (Bodungen et al. 1987; Wefer et al. 1988), or attenuation rates have not been calculated (Cadée et al. 1992; Accornero et al. 2003). The large seasonal and latitudinal variability in particle flux in the Southern Ocean (e.g., Honjo et al. 2000, 2008; Dubischar and Bathmann 2002 and refs within) makes it difficult to compare studies and combine all data to create a Martin type curve for sinking krill FP in the Southern Ocean. Where possible, we calculate FP attenuation rates from the literature to compare to our estimates of krill FP attenuation rate (Table 4). Previous studies, as collated in Table 4 (Wefer et al. 1988; Cadée et al. 1992; González 1992; Accornero et al. 2003; Cavan et al. 2015), highlight just how variable krill FP flux attenuation rates can be $(-1.81$ to 2.46 ).

Variability in attenuation rates may relate in part to the patchiness of krill swarms but also to the community composition in terms of the abundance of smaller flux feeding species. Previous studies have suggested that the density of individuals in krill swarms likely results in a 'rain' of
FP which may overload detrital feeders and pass mostly undisturbed through the upper mesopelagic (Atkinson et al. 2012; Belcher et al. 2016b; Barnes and Tarling in press). This has been hypothesised as an explanation for high numbers of krill pellets collected in sediment traps in the meso- and upper bathypelagic; however, full understanding of the processes driving these fluxes is still lacking. Lower abundances of small copepods such as Triconia spp. (previously Oncaea spp.) and Oithona spp. (often associated with flux feeding, fragmentation, and increased recycling) at our study site compared to more northerly sites in the Scotia Sea (Ward et al. 2012) may contribute to the low attenuation in FP flux $\left(b_{\mathrm{MSC}}\right)$ that we observed (Belcher et al. 2016b). Higher abundances of flux feeding zooplankton can lead to increased retention of FP (González 1992); however, with the high FP production associated with high krill densities in krill swarms, this flux feeding capacity is still likely overloaded. Thus, it is likely that given high enough densities, krill can drive high FP fluxes through the mesopelagic even in the presence of this retention filter. The zooplankton abundance and community structure is, therefore, an important control on flux attenuation (Belcher et al. 2016b).

We show that krill FP can make up a large component of the carbon flux in the South Orkneys MIZ region in spring, which is likely a combination of high FPP and low attenuation. Our MSC data, therefore, add to the evidence for high 
Table 4 Comparison of krill faecal pellet (FP) fluxes and attenuation rates

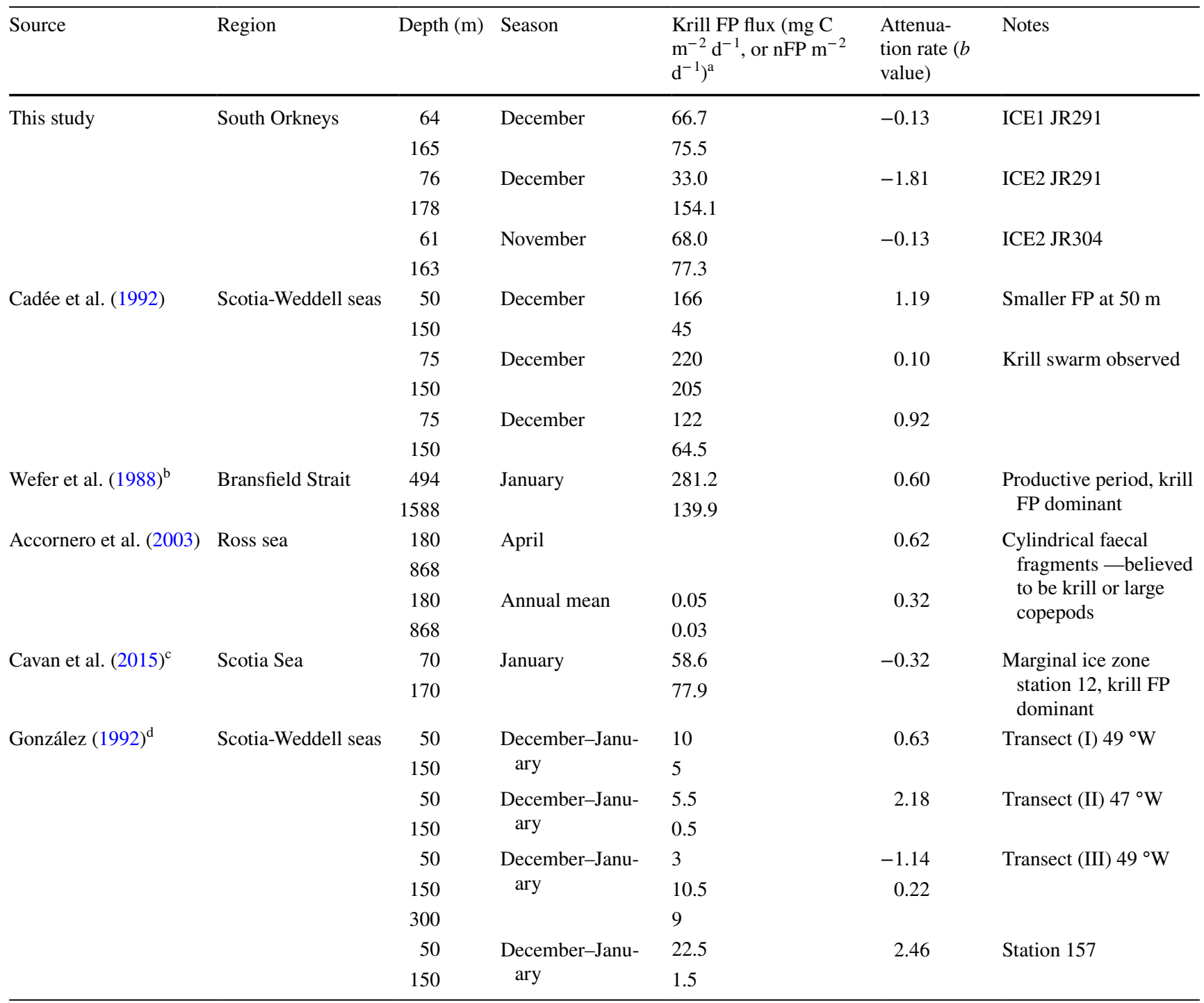

${ }^{a}$ All fluxes refer to the carbon flux, with the exception of Cadée et al. (1992), where fluxes are given in terms of the number of krill FP strings

${ }^{\mathrm{b}}$ Fluxes are for total particulate organic carbon

${ }^{c}$ Fluxes are for all FP, but krill FP were dominant

${ }^{\mathrm{d}}$ Fluxes are FP in terms of FP dry weight, and have been estimated from Figs. 3 and 5 of González (1992)

sinking rates of krill FP, high fluxes, and seemingly low attenuation rates. However, further studies are required to resolve respective contributions of FPP and attenuation to the net flux of krill FP to understand the mechanisms driving high krill FP fluxes in the mesopelagic. Consensus is needed on krill FP attenuation before we can start to model the role of krill in biogeochemical cycling. We suggest that calculating krill FP attenuation rates from measurements of krill density, FPP, and mesopelagic krill FP fluxes in other high-density krill areas in the Southern Ocean would enable the contribution of krill FP to the $\mathrm{BCP}$ to be more fully assessed, particularly with regard to whether it holds the same importance as in the present study region. This would require a series of acoustic transects for krill density and measurement of particle flux at regular spatial intervals within this survey grid. Direct measurements of krill FP egestion would also be needed, including measurement of FP carbon contents. The calculated krill FP attenuation rates would also allow predictions of how future changes in krill densities might impact the Southern Ocean BCP.

Acknowledgements We would like to thank the crew, officers, and scientific party of research cruises JR291, JR304 aboard the RSS James Clark Ross. In particular, we would like to thank Elena Ceballos Romero, Fred le Moigne, Andy Richardson, and Manon Duret for their help deploying Marine Snow Catchers at all hours of the day and night! Additionally we would like to thank the editor and two 
anonymous reviewers, whose suggestions helped improve the manuscript. Work was funded by the NERC studentship of Anna Belcher (NE/ 1362197). Fieldwork was supported by a NERC AFI Collaborative Gearing Scheme grant to Stephanie Henson. Geraint A. Tarling and Clara Manno were supported by the Ocean Ecosystems programme at British Antarctic Survey.

Open Access This article is distributed under the terms of the Creative Commons Attribution 4.0 International License (http:// creativecommons.org/licenses/by/4.0/), which permits unrestricted use, distribution, and reproduction in any medium, provided you give appropriate credit to the original author(s) and the source, provide a link to the Creative Commons license, and indicate if changes were made.

\section{References}

Accornero A, Manno C, Esposito F, Gambi MC (2003) The vertical flux of particulate matter in the polynya of Terra Nova Bay. Part II. Biological components. Antarct Sci 15:175-188. doi:10.1017/ S0954102003001214

Alldredge AL (1998) The carbon, nitrogen and mass content of marine snow as a function of aggregate size. Deep Sea Res Part I Oceanogr Res Pap 45:529-541. doi:10.1016/S0967-0637(97)00048-4

Atkinson A, Siegel V, Pakhomov EA et al (2008) Oceanic circumpolar habitats of Antarctic krill. Mar Ecol Prog Ser 362:1-23. doi: $10.3354 /$ meps07498

Atkinson A, Schmidt K, Fielding S, et al (2012) Variable food absorption by Antarctic krill: Relationships between diet, egestion rate and the composition and sinking rates of their fecal pellets. Deep Sea Res Part II Top Stud Oceanogr 59-60:147-158. doi:10.1016/j.dsr2.2011.06.008

Barnes DKB, Tarling GA (in press) Polar oceans in a changing climate. Curr Biol

Bathmann U, Fischer G, Müller PJ, Gerdes D (1991) Short-term variations in particulate matter sedimentation off Kapp Norvegia, Weddell Sea, Antarctica: relation to water mass advection, ice cover, plankton biomass and feeding activity. Polar Biol 11:185195. doi:10.1007/BF00240207

Beaulieu S (2002) Accumulation and fate of phytodetritus on the sea floor. Oceanogr Mar Biol Annu Rev 40:171-232. doi:10.1201/9780203180594.ch4

Belcher A, Iversen M, Giering S et al (2016a) Depth-resolved particle associated microbial respiration in the northeast Atlantic. Biogeosciences 13:4927-4943. doi:10.5194/bg-2016-130

Belcher A, Iversen MH, Manno C et al (2016b) The role of particle associated microbes in remineralization of fecal pellets in the upper mesopelagic of the Scotia Sea, Antarctica. Limnol Oceanogr 61:1049-1064. doi:10.1002/lno.10269

Belcher A, Manno C, Ward P et al (2017) Copepod faecal pellet transfer through the meso- and bathypelagic layers in the Southern Ocean in spring. Biogeosciences 14:1511-1525. doi:10.5194/ bg-14-1511-2017

Bidigare R, Hanson L, Buesseler KO et al (1999) Iron-stimulated changes in $13 \mathrm{C}$ fractionation and export by equatorial Pacific phytoplankton: toward a paleogrowth rate proxy. Paleoceanography 14:589-595. doi:10.1029/1999PA900026

Bodungen B Von, Fischer G, Nothing EM, Wefer G (1987) Sedimentation of krill faeces during spring development of phytoplankton in the Bransfield Strait, Antarctica. Mitteilungen aus dem Geol un Paläontologischen Inst der Univ Leipzig 62:243-235

Boyd P, Laroche J, Gall M et al (1999) Role of iron, light, and silicate in controlling algal biomass in subantarctiv waters SE of
New Zealand. J Geophys Res 104:13395-13408. doi:10.1029/ 1999JC900009

Buesseler KO, Ball L, Andrews J, et al (2001) Upper ocean export of particulate organic carbon and biogenic silica in the Southern Ocean along $170^{\circ} \mathrm{W}$. Deep Sea Res Part II Top Stud Oceanogr 48:4275-4297. doi:10.1016/S0967-0645(01)00089-3

Cadée GC (1992) Organic carbon and its sedimentation during the ice retreat period in the Wedell-Scotia Sea, 1988. Polar Biol 12:253-259. doi:10.1007/BF00238267

Cadée GC, González HE, Schnack-Schiel SB (1992) Krill diet affects faecal string settling. Polar Biol 12:75-80. doi:10.1007/ BF00239967

Cavan EL, Le Moigne F, Poulton AJ et al (2015) Attenuation of particulate organic carbon flux in the Scotia Sea, Southern Ocean, controlled by zooplankton fecal pellets. Geophys Res Lett 42:821-830. doi:10.1002/2014GL062744

Clarke A, Quetin LB, Ross RM (1988) Laboratory and field estimates of the rate of faecal pellet production by Antarctic krill, Euphausia superba. Mar Biol 98:557-563. doi:10.1007/ BF00391547

Dubischar CD, Bathmann U V. (2002) The occurrence of faecal material in relation to different pelagic systems in the Southern Ocean and its importance for vertical flux. Deep Res Part II Top Stud Oceanogr 49:3229-3242. doi:10.1016/S0967-0645(02)00080-2

Dunbar RB (1984) Sediment trap experiments on the Antarctic continental margin. Antarct J United States 19:70-71

Fielding S, Watkins JL, Collins MA et al (2012) Acoustic determination of the distribution of fish and krill across the Scotia Sea in spring 2006, summer 2008 and autumn 2009. Deep Res Part II 59-60:173-188. doi:10.1016/j.dsr2.2011.08.002

Fischer G, Fuetterer D, Gersonde R et al (1988) Seasonal variability of particle flux in the Weddell Sea and its relation to ice cover. Nature 335:426-428. doi:10.1038/335426a0

Gibbons M, Spiridonov V, Tarling GA (1999) Euphausiacea. In: Boltovskoy D (ed) South Atlantic zooplankton. Backhuys, Leiden, pp 1241-1279

Gleiber MR, Steinberg DK, Ducklow HW (2012) Time series of vertical flux of zooplankton fecal pellets on the continental shelf of the western Antarctic Peninsula. Mar Ecol Prog Ser 471:23-36. doi:10.3354/meps10021

Godlewska M, Klusek Z (1987) Vertical distribution and diurnal migrations of krill - Euphausia superba Dana-from hydroacoustical observations, SIBEX, December 1983/January 1984. Polar Biol 8:17-22. doi:10.1007/BF00297159

González HE (1992) The distribution and abundance of krill faecal material and oval pellets in the Scotia and Weddell Seas (Antarctica) and their role in particle flux. Polar Biol 12:81-91. doi:10.1007/BF00239968

Hamner W, Hamner P, Obst B (1989) Field observations on the ontogeny of schooling of Euphausia superba furciliae and its relationship to ice in Antarctic waters. Limnol Oceanogr 34:451-456. doi:10.4319/lo.1989.34.2.0451

Henson SA, Sanders R, Madsen E (2012) Global patterns in efficiency of particulate organic carbon export and transfer to the deep ocean. Global Biogeochem Cycles. doi:10.1029/2011GB004099

Hewitt RP, Watkins J, Naganobu M et al (2004) Biomass of Antarctic krill in the Scotia Sea in January/February 2000 and its use in revising an estimate of precautionary yield. Deep Sea Res Part II Top Stud Oceanogr 51:1215-1236. doi:10.1016/j. dsr2.2004.06.011

Hilton J, Lishman JP, Mackness S, Heaney SI (1986) An automated method for the analysis of "particulate" carbon and nitrogen in natural waters. Hydrobiologia 141:269-271. doi:10.1007/ BF00014221

Honjo S, Francois R, Manganini S et al (2000) Particle fluxes to the interior of the Southern Ocean in the Western Pacific 
sector along $170^{\circ} \mathrm{W}$. Deep Res Part II 47:3521-3548. doi:10.1016/S0967-0645(00)00077-1

Honjo S, Manganini SJ, Krishfield RA, Francois R (2008) Particulate organic carbon fluxes to the ocean interior and factors controlling the biological pump: a synthesis of global sediment trap programs since 1983. Prog Oceanogr 76:217-285. doi:10.1016/j. pocean.2007.11.003

Iversen MH, Ploug H (2013) Temperature effects on carbon-specific respiration rate and sinking velocity of diatom aggregatespotential implications for deep ocean export processes. Biogeosciences 10:4073-4085. doi:10.5194/bg-10-4073-2013

Iversen MH, Poulsen L (2007) Coprorhexy, coprophagy, and coprochaly in the copepods Calanus helgolandicus, Pseudocalanus elongatus, and Oithona similis. Mar Ecol Prog Ser 350:79-89. doi:10.3354/meps07095

Jouandet MP, Jackson GA, Carlotti F et al (2014) Rapid formation of large aggregates during the spring bloom of Kerguelen Island: Observations and model comparisons. Biogeosciences 11:43934406. doi:10.5194/bg-11-4393-2014

Kils U (1981) The swimming behavior, swimming performance and energy balance of Antarctic krill, Euphausia superba. SCAR Biomass Sci Ser 3:1-122

Kwon EY, Primeau F, Sarmiento JL (2009) The impact of remineralization depth on the air-sea carbon balance. Nat Geosci 2:630635. doi:10.1038/ngeo612

Lancraft TM, Hopkins TL, Torres JJ, Donnelly J (1991) Oceanic micronektonic/macrozooplanktonic community structure and feeding in ice covered Antarctic waters during the winter (AMERIEZ 1988). Polar Biol 11:157-167. doi:10.1007/ BF00240204

Laurenceau-Cornec EC, Trull TW, Davies DM et al (2015) The relative importance of phytoplankton aggregates and zooplankton fecal pellets to carbon export: insights from free-drifting sediment trap deployments in naturally iron-fertilised waters near the Kerguelen Plateau. Biogeosciences 12:1007-1027. doi:10.5194/ bg-12-1007-2015

Manno C, Stowasser G, Enderlein P et al (2015) The contribution of zooplankton faecal pellets to deep-carbon transport in the Scotia Sea (Southern Ocean). Biogeosciences 12:1955-1965. doi:10.5194/bg-12-1955-2015

Martin JH, Knauer GA, Karl DM, Broenkow WW (1987) VERTEX: carbon cycling in the northeast Pacific. Deep Sea Res Part I Oceanogr Res Pap 34:267-285. doi:10.1016/0198-0149(87)90086-0

Menden-Deuer S, Lessard EJ (2000) Carbon to volume relationships for dinoflagellates, diatoms, and other protist plankton. Limnol Oceanogr 45:569-579

Miquel J-C, Gasser B, Martín J et al (2015) Downward particle flux and carbon export in the Beaufort Sea, Arctic Ocean; the role of zooplankton. Biogeosciences 12:5103-5117. doi:10.5194/ bg-12-5103-2015

Nordhausen W, Huntley ME (1990) RACER: carbon egestion rates of Euphausia superba. Antarct J United States 25:161-162

Pakhomov EA, Perissinotto R, Froneman PW, Miller DGM (1997) Energentics and feeding dynamics of Euphausia superba in the South Georgia region during the summer of 1994. J Plankton Res 19:399-423. doi:10.1093/plankt/19.4.399

Ploug H, Jorgensen BB (1999) A net-jet flow system for mass transfer and microsensor studies of sinking aggregates. Mar Ecol Prog Ser 176:279-290. doi:10.3354/meps176279

Pollard RT, Salter I, Sanders RJ et al (2009) Southern Ocean deepwater carbon export enhanced by natural iron fertilization. Nature 457:577-580. doi:10.1038/nature07716

Poulsen L, Kiørboe T (2005) Coprophagy and coprorhexy in the copepods Acartia tonsa and Temora longicornis: clearance rates and feeding behaviour. Mar Ecol Prog Ser 299:217-227. doi:10.3354/meps299217

Primeau FW, Holzer M, DeVries T (2013) Southern Ocean nutrient trapping and the efficiency of the biological pump. J Geophys Res 118:2547-2564

Rembauville M, Blain S, Armand L et al (2015) Export fluxes in a naturally iron-fertilized area of the Southern Ocean-part 2: importance of diatom resting spores and faecal pellets for export. Biogeosciences 12:3171-3195. doi:10.5194/bg-12-3171-2015

Riley JS, Sanders R, Marsay C et al (2012) The relative contribution of fast and slow sinking particles to ocean carbon export. Global Biogeochem Cycles. doi:10.1029/2011GB004085

Roca-Marti M, Puigcorbé V, Iversen MH et al (2015) High particulate organic carbon export during the decline of a vast diatom bloom in the Atlantic sector of the Southern Ocean. Deep Res Part II. doi:10.1016/j.dsr2.2015.12.007

Savoye N, Trull TW, Jacquet SHM et al (2008) 234Th-based export fluxes during a natural iron fertilization experiment in the Southern Ocean (KEOPS). Deep Res Part II Top Stud Oceanogr 55:841-855. doi:10.1016/j.dsr2.2007.12.036

Schmidt K, Atkinson A (2016) Feeding and food processing in Antarctic Krill (Euphausia superba Dana). In: Siegel V (ed) Biology and ecology of antarctic krill. Springer, Cham, pp 175-224

Schmidt K, Atkinson A, Venables HJ, Pond DW (2012) Early spawning of Antarctic krill in the Scotia Sea is fuelled by "superfluous" feeding on non-ice associated phytoplankton blooms. Deep Res Part II Top Stud Oceanogr 59-60:159-172. doi:10.1016/j. dsr2.2011.05.002

Schmidt K, Schlosser C, Atkinson A et al (2016) Zooplankton gut passage mobilizes lithogenic iron for ocean productivity. Curr Biol 26:2667-2673. doi:10.1016/j.cub.2016.07.058

Siegel V, Kawaguchi S, Ward P et al (2004) Krill demography and large-scale distribution in the southwest Atlantic during January/ February 2000. Deep Res Part II 51:1253-1273. doi:10.1016/j. dsr2.2004.06.013

Skaret G, Krafft BA, Calise L et al (2015) Evaluation of Antarctic krill biomass and distribution off the South Orkney Islands 2011-2015. SC-CAMLR-WG-EMM 15/54:1-20

Smetacek VS (1985) Role of sinking in diatom life-history cycles: ecological, evolutionary and geological significance. Mar Biol 84:239-251. doi:10.1007/BF00392493

Smetacek V, Klaas C, Strass VH et al (2012) Deep carbon export from a Southern Ocean iron-fertilized diatom bloom. Nature 487:313-319. doi:10.1038/nature11229

Smith WO, Nelson DM (1985) Phytoplankton Bloom Produced by a receding ice edge in the Ross Sea: Spatial coherence with the density field. Science 227:163-166. doi:10.1126/ science. 227.4683 .163

Svensen C, Wexels Riser C, Reigstad M, Seuthe L (2012) Degradation of copepod faecal pellets in the upper layer: role of microbial community and Calanus finmarchicus. Mar Ecol Prog Ser 462:39-49. doi:10.3354/meps09808

Svensen C, Morata N, Reigstad M (2014) Increased degradation of copepod faecal pellets by co-acting dinoflagellates and Centropages hamatus. Mar Ecol Prog Ser 516:61-70. doi:10.3354/ meps 10976

Taki K, Hayashi T, Naganobu M (2005) Characteristics of seasonal variation in diurnal vertical migration and aggregation of antarctic krill (Euphausia superba) in the Scotia Sea, using Japanese fishery data. CCAMLR Sci 12:163-172

Tarling GA, Fielding S (2016) Swarming and behaviour in Antarctic krill. In: Siegel V (ed) Biology and ecology of Antarctic krill. Springer International Publishing, Switzerland, pp 279-319

Tarling GA, Johnson ML (2001) Satiation gives krill that sinking feeling. Curr Biol 16:83-84. doi:10.1016/j.cub.2006.01.044 
Taucher J, Bach LT, Riebesell U, Oschlies A (2014) The viscosity effect on marine particle flux: a climate relevant feedback mechanism. Global Biogeochem Cycles 28:415-422. doi:10.1002/20 13GB004728

Trull TW, Bray SG, Buesseler KO et al (2008) In situ measurement of mesopelagic particle sinking rates and the control of carbon transfer to the ocean interior during the Vertical Flux in the Global Ocean (VERTIGO) voyages in the North Pacific. Deep Sea Res Part II Top Stud Oceanogr 55:1684-1695. doi:10.1126/ science.1137959

Urrere MA, Knauer GA (1981) Zooplankton fecal pellet flaxes and vertical transport of participate organic material in the pelagic environment. J Plankton Res 3:369-387. doi:10.1093/ plankt/3.3.369

Ward P, Atkinson A, Tarling G (2012) Mesozooplankton community structure and variability in the Scotia Sea: a seasonal comparison. Deep Sea Res Part II Top Stud Oceanogr 59-60:78-92. doi:10.1016/j.dsr2.2011.07.004

Wefer G, Fischer G, Fuetterer D, Gersonde R (1988) Seasonal particle flux in the Bransfield Strait, Antarctica. Deep Sea Res 35:891898. doi:10.1016/0198-0149(88)90066-0 